\title{
IAMJ
}

INTERNATIONAL

AYURVEDIC

MEDICAL JOURNAL

\section{EFFECT OF PSYCHOLOGICAL FACTORS IN KESHA VIKARA (HAIR RELATED DISORDERS): A REVIEW ARTICLE}

\section{$\underline{\text { Verity Markhap }}^{1}$, Khagen Basumatary ${ }^{2}, \underline{\text { Karab Ali }}^{3}$}

${ }^{1}$ PG Scholar, Dept of Samhita and Siddhanta, Govt. Ayurvedic College and Hospital, Guwahati, Assam, India ${ }^{2}$ Professor and head, Dept. of Samhita and Siddhanta, Govt. Ayurvedic College and Hospital, Guwahati, Assam, India

${ }^{3}$ Assistant Professor, Dept. of Samhita and Siddhanta, Govt. Ayurvedic College and Hospital, Guwahati, Assam, India

Corresponding Author: markhapverity@gmail.com

\section{https://doi.org/10.46607/iamj3409082021}

(Published Online: August 2021)

Open Access

(C) International Ayurvedic Medical Journal, India 2021

Article Received: 23/07//2021 - Peer Reviewed: 02/08/2021 - Accepted for Publication: 03/08/2021

\section{Check for updates}

\section{ABSTRACT}

Trichology is the study of hair and scalp, the Ayurvedic classics presents many such contexts which can contribute to understanding the concept of trichology in Ayurveda. Hair related disorders are one of the challenging diseases in today's world, where every person is conscious about their outer physical appearance, hair being one of most of the most important features. Nowadays, Stress has been one of the leading roles in causing diseases, many studies depict the relation of stress and hair related disorders also. Understanding and analyzing the various concept of trichology in Ayurveda, correlating with the other established studies would aid in a proper understanding of the role of a psychological factor in the causation of Kesha Vikara (Hair related disorder).

Keywords: Ayurveda, trichology, psychological factors, hair related disorder. 


\section{INTRODUCTION}

'Let your hair do the talking' The sayings highlight the significant role of hair for every person in society. It associates with youthfulness and beauty in women or masculinity and virility in men. It is an indicator of both social and professional status. Ayurveda, which propagates equal importance to curative and preventive aspects have described hair in a various context which can be co-related to Trichology, the study of hair and scalp. Hair is one of the important features in terms of appearance, has many other roles for the maintenance of health. Since the medieval period, it has been one of the neglected parameters. In the present scenario with the increased level of lifestyle disorders, the need for understanding the preventive aspects stands first. Many psychological factors like stressful situations, anxiety etc. are considered to have a leading role in the aetiology of hair related disorders. Trichology, being one of the important parameters to understand these disorders, a detailed study as per the reference given in Ayurveda is required. Ayurveda presents many such contextual presentations of psychological concepts in Kesha vikara (hair related disorders). Increased level of psychological factors hampering the normal physiology of hair is to be considered and analyzed.

\section{MATERIAL AND METHOD:}

Along with the multiple pathophysiological factors affecting hair, there is a very broad spectrum of possible psychological disorders related to hair disorders. Even though works and researches are being done, a complete understanding is still insufficient. As per Ayurveda, the study of the pathogenesis of hair related disorders and the Dosha involved provides a better understanding of the psychological impact. To understand the role of psychological factors in Hair related disorders according to Ayurveda, first most the general Samprapti (pathogenesis) of hair related disorders is considered, after which the other concepts can be correlated and analyzed to conclude.

\section{Samprapti (pathogenesis) of hair related disor- ders in Ayurveda:}

Hair related disorders are given differently by the various Acharyas. Acharya Susruta has mentioned Darunaka (dandruff), Indralupta (hair fall), pallitya (greying of hair), Arumshika. ${ }^{1}$ Acharya Charaka has mentioned Khalitya - pallitya (hair fall and greying of hair). ${ }^{2}$ Considering the pathogenesis of all of these disorders, the main aetiology is the involvement of Pitta dosha with other Dosha.

Nidana sevana
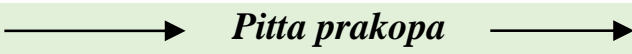

involves other doshas $\longrightarrow$ romakupa

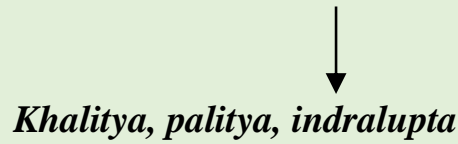

2. Role of psychological disorder in hair-related disorders:

Analysing the general Samprapti (pathogenesis) following inferences are interpreted:

i. Psychological factor causes MANDAGNI leading to an improper formation of Dosha, Dhatu, MalaKESHA.

A/c Su. Su.46.500,501 - food is taken with IRSHYA(jealousy), BHAYA(fear), KRODHA (anger) , LOBHI (desire) etc ${ }^{3}$

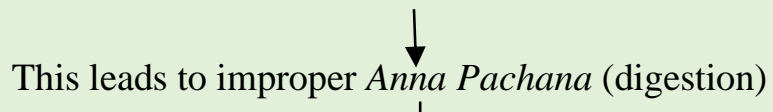

Which can be taken as Mandagni 


\section{Improper Ahara rasa and successive Dhatu formation.}

\section{Rasa Janya vikaras (Ch.Su.28.9) - Pallitya ${ }^{4}$}

ii. Psychological factors like Adheeka krodha(excessive anger), adheeka shoka (excessive depression), adheeka shrama (psychological exertion) leads to hair related disorders especially Palitya. ${ }^{5}$

\section{Adheeka krodha, shoka, shrama \\ Increased ushma in the Shiras}

\section{Does pakti of Roma/Palitya}

iii. Considering PITTA - main Doshas in all Kesha vikara (hair related disorders).

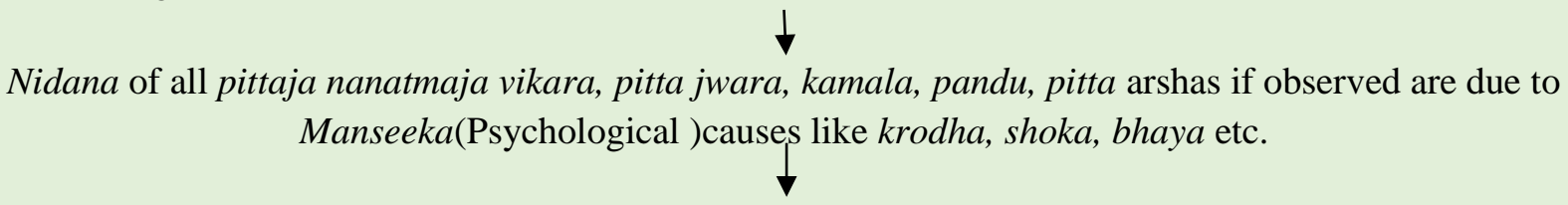

Thus it is inferred that Pitta aggravates due to psychological causes.

Pitta is the main Doshas causing hair related disorders. Understanding these concepts, it is understood that all psychological factors lead to Pitta aggravation and this in turn along with other doshas would either affect the ahara paka krama and alter the process of formation of hair or directly migrate to romakupa (scalp) and produces symptoms.

3. Stress and hair: On exposure to Stress various hormones are released as a response, known as the stress hormones. All living organisms are constantly challenged by a diversity of exogenous (environmental, psychological, social) and endogenous stimuli or stressors, which induce general or local biological responses to protect or adapt the organism to the stressors. ${ }^{6}$ The systemic biological response of the organism to exogenous stressors includes activation of the hypothalamicpituitary-adrenal axis and release of specific hormones, which in turn modulate the function of various systems of the body. ${ }^{7}$ The hair follicle is richly innervated by sensory and autonomic nerve fibres. These nerve fibres form networks around the outer root sheath of the Hair follicle, they function as mechanoreceptors for all the neurotransmitters, hormones etc. There is various evidence that suggests that the neurohormones, cytokines released during the stress response may significantly influence the hair cycle. ${ }^{8}$ Actively growing hair follicles in mice and humans show expression of CRH-R1 and melanocortin-1 receptor(MC-1R) in the follicular epithelium and mesenchyme. ${ }^{9}$ Administration of ACTH induces premature hair follicle anagen-catagen transition. ${ }^{10}$ Glucocorticoids stimulate apoptosis in the follicular epithelium leading to premature hair follicle involution. ${ }^{11}$

\section{DISCUSSION}

Ayurveda presents many aspects of Trichology, the general Samprapti (pathogenesis) of hair related disorders signifies that pitta is the main dosha in Kesha vikara (hair related disorders). Psychological factor causes Mandagni leading to an improper formation of Dosha, Dhatu, Mala- Kesha according to Sushruta Acharya, Charaka further mentioned Mandagni for improper rasa formation, which will cause Rasajanya Vikara like Palitya. Also, Sushruta Acharya quoted a direct concept where psychological factors like Adheeka krodha(excessive anger), adheeka shoka (excessive depression), adheeka shrama (psychological exertion) leads to hair related disorders 
especially Palitya. Another concept where it is observed that in all pittaja Vikara (diseases caused due to Pitta dosha), Mansika Nidana (psychological aetiology) have been mentioned, and considering Pitta as the main Doshas in all hair related disorders, the psychological factor in hair related disorder can be considered. All psychological factors lead to Pitta aggravation which along with other doshas would either affect the ahara paka krama (digestion process) and alter the process of formation of hair or directly migrate to romakupa (scalp) to produce hair-related symptoms. There is various evidence that suggests that the stress hormones, neurohormones, cytokines released during the stress response may significantly influence the hair cycle. Co-relating as per the contemporary view where it can be inferred that all psychological stress causes aggravation of stress hormones which can be correlated as Pitta dosha which according to Ayurveda is the main dosha in the causation of Kesha vikara (hair related disorders).

\section{CONCLUSION}

Along with the multiple pathophysiological factors affecting hair, there is a very broad spectrum of possible psychological disorders related to hair disorders. As per Ayurveda, the study of the pathogenesis of hair related disorders and the Dosha involved provided a better understanding of the psychological impact. Correlating the general Samprapti (pathogenesis) of hair related disorders with other Ayurvedic concepts like Rasajanya vikara, the pathogenesis of Palitya according to Sushruta, pitta vikara (diseases caused due to Pitta dosha) and their aetiology reveals that psychological factor plays an important role in the causation of kesha vikara (hair related disorders).

\section{REFERENCES}

1. Sharma, P.V. (2013). English translation of text and Dalhana ${ }^{\text {ee }}$ commentary along with critical notes on Sushrut Samhita vol 2, Chaukhamba Visvabharati prakashan, Varanasi, edition, Nidana sthana, 13/33,34,36,37

2. Bhagwan Dash, R.K. (2014). Sharma, text with English translation \& critical exposition based on Cakrapani dattaes $^{\text {ee }}$ Ayurveda Dipika, Charak Samhita, Chaukhamba Sanskrit Sansthan Varanasi, edition, Chikitsa sthana,26/132,133.

3. Sharma, P.V. (2013). English translation of text and Dalhanaes commentary along with critical notes on Sushrut Samhita vol 2, Chaukhamba Visvabharati prakashan, Varanasi, edition, Sushruta Sthana,46/500,501

4. Bhagwan Dash, R.K. (2014). Sharma, text with English translation \& critical exposition based on Cakrapani

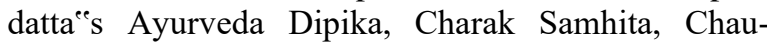
khamba Sanskrit Sansthan Varanasi, edition, Sutra sthana 28/9.

5. Sharma, P.V. (2013). English translation of text and Dalhanaes commentary along with critical notes on Sushrut Samhita vol 2, Chaukhamba Visvabharati prakashan, Varanasi, edition, Nidana Sthana.13/37.

6. Selye H: Forty years of stress research: principal remaining problems and misconceptions. Can Med Assoc $J$ 1976, 115:53-56 [PMC free article] [PubMed].

7. [Welch WJ: Mammalian stress response: cell physiology, structure/function of stress proteins, and implications for medicine and disease. Physiol $\operatorname{Rev} 1992,72: 1063-1081$ [PubMed]

8. Roloff B, Fechner K, Slominski A, Furkert J, Botchkarev VA, Bulfone-Paus S, Zipper J, Krause E, Paus R: Hair cycle-dependent expression of corticotropin-releasing factor and CRF receptors in murine skin. FASEB J 1998, 12:287-297 [PubMed]

9. Paus R, Botchkarev VA, Botchkareva NV, Mecklenburg L, Luger T, Slominski A: The skin POMC system (SPS). Leads and lessons from the hair follicle. Ann NY Acad Sci 1999, 885:350-363 [PubMed]

10. Paus R, Maurer M, Slominski A, Czarnetzki BM: Mast cell involvement in murine hair growth. Dev Biol 1994, 163:230-240 [PubMed].

11. Paus R, Handjiski B, Czarnetzki BM, Eichmüller S: A murine model for inducing and manipulating hair follicle regression (catagen): effects of dexamethasone and cyclosporin A.J Invest Dermatol 1994, 103:143-147 [PubMed].

\section{Source of Support: Nil \\ Conflict of Interest: None Declared}

How to cite this URL: Verity Markhap et al: Effect of Psychological Factors In Kesha Vikara (Hair Related Disorders): A Review Articles. International Ayurvedic Medical Journal \{online\} 2021 \{cited August 2021\} Available from:

http://www.iamj.in/posts/images/upload/1815_1818.pdf 